\title{
Gluten misconceptions and scam
}

Keywords: gluten, celiac disease, food production

\section{Introduction}

Gluten is nothing new; it has always been part of wheat-based products. Gluten is formed from flour storage proteins (glutenins and gliadins) when water is added. Recently, gluten comes into spotlight due to increase in the number of celiac patient. Celiac disease is an immune disorder that primarily truncates the villi of the small intestine in the genetically predisposed people due to reaction to $\alpha$-type gliadins. Global spread of celiac might be due to increasing in population, migration and inter-marriage. Also, increase in celiac cases can be due to increase in gluten concentration in food due to reduction in processing (mostly fermentation) time and addition of extra gluten in recent food production. ${ }^{1}$
Volume 8 Issue 2 - 2018

Tawakalit-T Asiyanbi-H,' Guerline Stanley,' Ademola M Hammed ${ }^{3}$

'Plant Science Department, North Dakota State University, USA

${ }^{2}$ Nursing Department, Stanford Hospital, Fargo, USA

${ }^{3}$ International Institute for Halal Research and Training.

International Islamic University Malaysia, Malaysia

Correspondence: Ademola M Hammed, International Institute for Halal Research and Training, International Islamic University Malaysia, Malaysia,Email demmarss@gmail.com

Received: November 03, 2017 | Published: March 152018

\section{Gluten misconceptions}

The concern of gluten-health relationship has led development gluten-free products. However, there is wide spread of misconceptions

about celiac disease, wheat products and gluten-free products (Table $1)$.

Table I Clarification of gluten misconceptions

\begin{tabular}{ll}
\hline Misconceptions & Clarification \\
\hline $\begin{array}{l}\text { Gluten free products are nutritional } \\
\text { richer that wheat-based products. }\end{array}$ & $\begin{array}{l}\text { Gluten-free products are usually low in dietary fiber unfortified. }{ }^{2} \text { Their protein content is often } \\
\text { less than wheat-based products. }\end{array}$ \\
$\begin{array}{l}\text { Gluten free products are non-wheat } \\
\text { product. }\end{array}$ & $\begin{array}{l}\text { Gluten free products are from alcohol-treated wheat flour which has had part of its gliadin } \\
\text { removed. }\end{array}$ \\
$\begin{array}{l}\text { Gluten is dangerous to all. } \\
\text { Gluten is not a bad protein for all but for few - the celiac disease patient i.e I\% of the global } \\
\text { peliac disease is only cause by wheat } \\
\text { gluten. }\end{array}$ & $\begin{array}{l}\text { Celiac disease is also cause by gluten forming protein and other homologous proteins from other } \\
\text { plant including barley, oat and rye. }{ }^{3}\end{array}$ \\
Gluten-gliadin has become more potent. & $\begin{array}{l}\text { Recently proteomic study showed that wheat gliadin has not changed over several decades of } \\
\text { breeding programs. }\end{array}$ \\
Avoiding gluten help in weight loss. & Gluten-free products are often made with flours with higher glycemic index than wheat . ${ }^{2}$ \\
\hline
\end{tabular}

\section{Gluten scam}

Currently, celiac disease can only be prevented by complete abstinence of gluten containing products. Many products are now being labelled as gluten free mostly to attract consumers' patronage. The additional processing cost make gluten-free products costlier than conventional wheat based products. As at 2010, the total sales of gluten-free products were estimated to be $\$ 2.5$ billion. ${ }^{2}$ Taking advantages of the aforementioned misconception, fair of gluten is now a tool to scam many consumers of their hard earned income.

Adequate understanding of gluten-health and-market relationships enhances consumers' choice of gluten-free products to be based on necessity.

\section{Acknowledgment}

Author declares no acknowledgment.

\section{Conflict of interest}

Author declares no conflict of interest.

\section{References}

1. Hammed AM, Simsek S. Hulled wheats: a review of nutritional properties and processing methods. Cereal Chemistry. 2014;91(2):97104.

2. Cross C. Gluten-free industry is healthy, but is the food? CMAJ 2013;185(13):E610.

3. Malalgoda M, Simsek S. Celiac disease and cereal proteins. Food Hydrocolloids. 2017;68(Suppl C):108-113. 